\title{
A Study on Nutritional Status and Dental Caries in Permanent Teeth among School Going Girl of Bengalee Population, India
}

\author{
Madhumati Chatterjee, Arup Ratan Bandyopadhyay* \\ Department of Anthropology, University College of Science, Technology and Agriculture, \\ University of Calcutta, Kolkata, India \\ Email: *arup_cu@rediffmail.com, *abanthro@caluniv.ac.in
}

Received June $4^{\text {th }}, 2012$; revised July $5^{\text {th }}, 2012$; accepted July $15^{\text {th }}, 2012$

\begin{abstract}
Variations in tooth eruption patterns are supposed to have multifactorial reasons and etiologic factors to explain variation in caries are unsatisfactory. Prevalence of caries is comparatively higher in the children of developing countries than that of the children of same age in developed countries. Indian studies on the dental caries mostly in children related to prevalence and treatment. However, nutritional effect on dental caries on Indian school going children is yet to be carried out in eastern India. This study investigated the prevalence of dental caries in permanent teeth and nutritional status among the 544 school going children (girls) of 6 - 19 years age group of Bengalee ethnicity of West Bengal, India. Caries was recorded based on DMFT index following basic guidelines for Oral Health Surveys guideline (WHO). Nutritional status was obtained using BMI and classification of nutritional status was achieved using the standards of WHO and CDC growth charts include an age- and sex-specific BMI reference for children aged 2 - 20 years. The overall prevalence of dental caries was $44.5 \%$ and mean DMFT was $0.45 \pm 1.57$. Nutritional status demonstrated, about $30 \%$ and $6.69 \%$ of schools going girls were underweight and overweight respectively. Occurrence of dental caries was found in all permanent teeth among the girls of underweight and normal according to their BMI-for age status. Furthermore, a significant association $(p<0.05)$ with occurrence of dental caries among the underweight girls has been found compared to that of the overweight and normal. This study indicates a close relationship between nutritional status and dental caries in this region.
\end{abstract}

Keywords: Dental Caries; Permanent Teeth; Nutritional Status

\section{Introduction}

Variations in tooth eruption patterns are supposed to have Multifactorial reasons (Robinow, 1973; Reid \& Dean, 2005) and also generally accepted etiologic factors are unsatisfactory to explain variation in caries in observational studies (Granath et al., 1991). Dental caries is a global disease with few populations exempt from its effects. In developing countries, as development increases so does dental caries and children are at the forefront of the disease disadvantage (Naidoo \& Myburgh, 2007). The strongest association, however, emerges to occur between dental eruption and skeletal growth (Garn et al., 1960; Demirjian et al., 1985). Early under nutrition in childhood affects skeletal growth and results in decreased height. Similarly, poor nutrition affects tooth eruption and outcome demonstrated delayed emergence of the deciduous teeth. There appears to be a physiological association between skeletal growth and tooth eruption (Barrett \& Brown, 1966; Mukherjee, 1973; RamiReddy et al., 1986; Banerjee et al., 1992; Alvarez, 1995; Chiu et al., 2012). A change in the pattern of tooth eruption should result in a concomitant change in the age distribution of dental caries in the primary teeth. Russell et al., (1965) reported that caries was substantially more severe in the deciduous teeth than permanent teeth with substantial ethnic variability (Yassin \& Low, 1975) regard to dental caries in both deciduous and permanent teeth have also been observed (Ludwig et al., 1964). Dental diseases impact considerably on self-esteem and quality

\footnotetext{
*Corresponding author.
}

of life and are expensive to treat. Study regarding caries prevalence among three distinct ethnic groups of five-year-old children demonstrated that mean caries prevalence values were higher among the Asian children (Prendergast et al., 1989). In children from less-developed countries, the prevalence of caries in deciduous teeth was found to be traditionally high in comparison to that of the children of same ages in developed countries and it is either similar or frequently higher (Russel, 1966; Mascarenhas, 1999; Cleaton-Jones et al., 2006). Indian studies on dental caries mostly carried out in adult and elderly population (Shah, 2003; Shah \& Sundaram, 2004) in relation to sociodemography, hygiene, and diet and in children (Mandal et al., 2001; Mahejabeen et al., 2006) related to prevalence and treatment as well. However, effect of nutrition in dental caries on Indian school children is yet to be carried out.

The present study is an attempt to investigate the effect of nutrition on caries development in permanent dentition among the school going girls of Howrah district, West Bengal, India. To best of the knowledge no studies has been reported on nutriational status and dental caries in permanent dentition among Eastern Indian population so far.

\section{Materials and Methods}

The cross-sectional study has been conducted on randomly selected 544 socio-economically middle class schoolgirls determined on the basis of their parents' income of Bengalee origin from Howrah district of West Bengal, India with the age range of 6 to 19 years and the mean age being $12.05 \pm 3.23 \mathrm{SD}$ 
years. Age of the girls has been obtained by confirming the date of birth from the school register. Dental eruption has been studied on the basis of the presence of crown in the gum and as well as by the shape, size, colour and sharpness for the permanent dentition. After taking consent from the individuals, apart from data regarding dental eruption and observation of caries, other biosocial information regarding monthly household income, number of family members, parity, birth order, hygiene practices etc. was taken by a specially prepared pre-tested schedule.

The study participants were examined for oral evaluations on an upright chair in adequate natural light using dental mouth mirror and explorer, following the World Health Organization's Basic Guidelines for Oral Health Surveys (WHO, 1997). Caries was recorded based on DMFT (Decayed, Missing and Filled Teeth) index. Nutritional status was evaluated by anthropometry taken from each girl following standard techniques (Lohman et al., 1988; Malina \& Bouchard, 2004). Stature were measured to the nearest $0.1 \mathrm{~cm}$ while, while weight was measured to the nearest $0.1 \mathrm{~kg}$ with least clothing by the female investigator. BMI was calculated as weight $(\mathrm{kg}) /$ Stature $^{2}(\mathrm{~m})$ and classification of nutritional status was achieved using the standard of WHO (1995) and also new growth charts from the Centers for Disease Control and Prevention (CDC) include an age- and sex-specific BMI reference for children aged 2 - 20 year (Kuczmarski et al., 2000, 2002) has been followed. All continuous variables were checked for normality and were found to be not negatively skewed. All data were double checked for any possible typological error. Technical error of measurement (TEM) (Ulijaszek \& Lourie, 1994) values was found to be between 0.000 and 0.351 considering the anthropometric variables. All statistical analyses have been done with the help of SPSS 9.0 statistical software.

\section{Results and Discussion}

The characteristics of the studied population (Table 1) demonstrated a steady increase of stature and weight from 6 - 10 years of age group to 15 - 19 years of age group. So far the nutritional status concern all the age groups revealed almost similar frequency of underweight (BMI $<5$ th percentile), while the 11 - 14 years of age group demonstrated slightly higher overweight (BMI $>$ 85th percentile) in comparison to 6 - 14 and 15 - 19 years of age group. It would be apparent from Table 1 that, the prevalence of dental caries was found to be highest in 11 - 14 years of age group (20.07\%) compared to those of 6 14 years and 15 - 19 years of age group. The median ages of the eruption of the permanent teeth in the present Bengalee School going girls demonstrated (Table 2) earlier eruption of mandibular and maxillary central Incisor. Late eruption was noticed in maxillary second Molar teeth, while permanent canine teeth demonstrated late eruption in both the maxilla and mandible. Examination on dental eruption revealed total absence of third molar in the present sample. The median age of eruption of permanent dentition, however, in corroboration within the range of Indian samples (Kaul et al., 1975; Bhasin et al., 1977; Kaul \&

Table 1.

Characteristics of the studied population.

\begin{tabular}{|c|c|c|c|}
\hline \multirow{2}{*}{ Variables } & \multicolumn{3}{|c|}{ Age Group } \\
\hline & $6-10$ Years & $11-14$ Years & $15-19$ Years \\
\hline \multicolumn{4}{|l|}{ Anthropometry } \\
\hline Stature $(\mathrm{cm})$ & $125.73 \pm 8.27$ & $147.87 \pm 7.66$ & $153.74 \pm 4.36$ \\
\hline Weight (kg) & $26.02 \pm 9.64$ & $42.86 \pm 11.06$ & $50.29 \pm 11.05$ \\
\hline \multicolumn{4}{|l|}{ Nutritional Status } \\
\hline Underweight (BMI < 5th Percentile) & $9.88 \%$ & $10.76 \%$ & $9.36 \%$ \\
\hline Overweight (BMI > 85th Percentile) & $2.22 \%$ & $3.39 \%$ & $1.08 \%$ \\
\hline \multicolumn{4}{|l|}{ Caries Prevalence } \\
\hline Prevalence of Carries & $11.34 \%$ & $20.07 \%$ & $13.09 \%$ \\
\hline
\end{tabular}

Table 2.

Median age (in years) of eruption of permanent teeth among Bengalee School girls.

\begin{tabular}{ccccc}
\hline & Maxilla & & Mandible \\
\hline Permanent Teeth & Upper Left & Upper Right & Lower Left & Lower Right \\
Medial Incisor (I1) & 6.2 & 5.7 & 5.6 & 5.7 \\
Lateral Incisor (I2) & 7.7 & 7.2 & 6.6 & 6.7 \\
Canine (C) & 11.3 & 11.2 & 11.5 & 11.4 \\
First Premolar (P1) & 10.1 & 10.2 & 11.3 & 11.5 \\
Second Premolar (P2) & 10.9 & 11.4 & 5.9 & 11.9 \\
First Molar (M1) & 6.2 & 6.0 & 11.9 & 5.9 \\
Second Molar (M2) & 10.9 & 11.5 & & 11.9 \\
\hline
\end{tabular}


Pathak, 1983) but a secular trend of early eruption of all permanent teeth has been noticed in comparison to prior study conducted on Bengalee School going girls (Banerjee et al., 1985).

In the present sample (544) about $30 \%$ of school going girls were underweight, while normal and overweight were $63.08 \%$ and $6.92 \%$ respectively, on the basis of BMI-for age. Examination on BMI-for age among the girls with dental caries revealed about $41.83 \%$ of the girls was underweight (Table 3) and $41.18 \%$ of the girls were normal. On the other hand about $17 \%$ of the girls with dental caries were overweight.

The overall prevalence of dental caries was $44.5 \%$ and the mean DMFT was found to be $0.45 \pm 1.57$. A trend of age effect on DFMT has been found in terms of higher occurrence of dental caries in higher ages. Occurrence of dental caries was found in all kinds of permanent dentition among the girls of underweight and normal according to their BMI-for age status. Contrary to that overweight girls demonstrated teeth wise variation in occurrence of dental caries and complete absence in Premolars. A significant association with occurrence of dental caries $(p<0.05)$ among the underweight girls has been found compared to that of the overweight and normal $(p<0.05)$. Teeth wise comparison, however, revealed almost similar incidences of dental caries among the underweight and normal girls with slightly higher incidences of caries in Molar teeth among the normal girls. Dental caries in Canine were found to be significantly ( $p<0.05$ ) higher among the overweight girls in comparison to their normal and underweight counterparts. In general the occurrence of dental caries has been noticed mostly (33.99\%) in Molars, followed by Incisors (32.02\%) and Premolars (14.38\%).

Although dental caries has been declining globally in general population, more so among adults, but the caries prevalence in younger age has not shown a significant decline. Majority of the studies were on school going children because of their accessibility (Holm, 1990) which is not so in preschool children. In the present study prevalence of dental caries in permanent dentition demonstrate lower incidences (44.1\%) than the finding of Mahejabeen et al., (2006) from southern part of India in preschool children and in corroboration with the study from Eastern India (Mondal et al., 2001) and as well as mean DMFT among the school children of Kerala, India (David et al., 2005). The overall nutritional status in terms of BMI-for age in the present study among the Bengalee School going girls, however, corroborate with earlier studies (Ghosh \& Bandyopadhyay, 2006; Ghosh \& Bandyopadhyay, 2009) on Bengalee schoolgirls and adults. Examination on prevalence of dental caries in the present study revealed that the underweight group was significantly higher $(p<0.05)$ than normal and overweight categories. However, cross sectional study from South East Asia (Narksawat et al., 2009) also revealed normal and thin schoolchildren had a higher risk for dental caries than overweight and obese children aged 12 - 14 years. Longitudinal study (DelgadoAngulo et al., 2012) demonstrated stunting being one of the risk factors of dental caries in permanent dentition as well. Oral health and nutrition have a synergistic bidirectional relationship and nutrition and diet may affect the development and integrity of the oral cavity towards the progression of oral diseases (Touger-Decker \& Mobley, 2007). Under nutrition in children not only delay the teeth development and affect the age distribution of dental caries, but also resulted in a higher number of carious primary teeth (Alvarez et al., 1990). The low socioeconomic class having the highest caries experience (Rahmatulla, 1993). Contrary to that, the tribal children exhibited a low prevalence of dental caries, both in primary and permanent dentitions, compared to rural and urban Indian children of the same age (Jalili, 1993; Rao \& Bharambhe, 1993; Honne, 2011).

Studies envisaged dental caries in deciduous dentition is a risk indicator for dental caries in permanent dentition (DelgadoAngulo, 2006) and caries status in the primary teeth can be used as a risk indicator for predicting caries in the permanent dentition (Li \& Wang, 2002). The multiple survival analysis confirmed that there has been major impact of the caries status of the deciduous dentition on the incidence of cavities in permanent molars (Leroy et al., 2005).

The use of peak caries activity has allowed the observation of a strong association between malnutrition and increased dental caries (Alvarez, 1995). It was found that chronic malnutrition vis a vis under nutrition reduced the secretion rate of stimulated saliva, but not that of unstimulated saliva. The salivary buffer capacity was continuously decreased as the secretion rate decreased with the level of malnutrition and under nutrition in the Indian children. The malnourished children developed increased caries and chronic malnutrition in growing children enhances the cariogenic potential stemming from fermentable carbohydrates (Johansson et al., 1992). Studies also demonstrated that the absence (Lenander-Lumikari \& Loimaranta, 2000; Uehara et al., 2003; Bergandi et al., 2007) due to deletion of locus (Klingberg, 2007) related to salivary soluble CD14 could represent a useful index of caries activity. Enamel hypoplasia, salivary glandular hypofunction and saliva compositional changes might be mechanisms through which malnutrition is associated with caries (Psoter et al., 2005). The pattern of dental

Table 3.

Incidences of dental caries in permanent teeth according to nutritional status represented by BMI in Bengalee School girls.

\begin{tabular}{|c|c|c|c|c|c|c|c|c|}
\hline \multirow{2}{*}{$\begin{array}{l}\text { Nutritional Status on the } \\
\text { Basis of BMI }\end{array}$} & \multicolumn{8}{|c|}{ Permanent Dentition } \\
\hline & $\mathrm{I} 1$ & I2 & $\mathrm{C}$ & $\mathrm{P} 1$ & P2 & M1 & M2 & Total \\
\hline $\begin{array}{c}\text { Underweight } \\
\text { BMI < 5th Percentile }\end{array}$ & $\begin{array}{c}15 \\
(23.43)\end{array}$ & $\begin{array}{c}8 \\
(12.50)\end{array}$ & $\begin{array}{c}10 \\
(15.63)\end{array}$ & $\begin{array}{c}8 \\
(12.50)\end{array}$ & $\begin{array}{c}3 \\
(4.69)\end{array}$ & $\begin{array}{c}12 \\
(18.75)\end{array}$ & $\begin{array}{c}8 \\
(12.50)\end{array}$ & 64 \\
\hline $\begin{array}{l}\text { Normal } \\
\text { BMI }\end{array}$ & $\begin{array}{c}20 \\
(31.75)\end{array}$ & $\begin{array}{c}3 \\
(4.76)\end{array}$ & $\begin{array}{c}2 \\
(3.17)\end{array}$ & $\begin{array}{c}7 \\
(11.4)\end{array}$ & $\begin{array}{c}4 \\
(6.35)\end{array}$ & $\begin{array}{c}12 \\
(19.05)\end{array}$ & $\begin{array}{c}15 \\
(23.81)\end{array}$ & 63 \\
\hline $\begin{array}{c}\text { Overweight } \\
\text { BMI > 85th Percentile }\end{array}$ & $\begin{array}{c}3 \\
(11.54)\end{array}$ & - & $\begin{array}{c}18 \\
(69.23)\end{array}$ & - & - & $\begin{array}{c}3 \\
(11.54)\end{array}$ & $\begin{array}{c}2 \\
(7.69)\end{array}$ & 26 \\
\hline
\end{tabular}

Note: Figures in the (parenthesis) denotes percentage. 
caries in the present sample demonstrated that the prevalence of caries in the posterior teeth overall increased among the underweight and normal girls compared to the anterior teeth. The similar pattern and findings has been found from India (Mahejabeen et al., 2006) and as well as from other parts of the world (Bjarnason et al., 1995; Kerosuo \& Honkala, 1991; O’Sullivan \& Tinanoff, 1996; Raadal et al., 1993).

This study indicates a close relationship between nutritional status and dental caries in this region. Thus, instilling the positive attitudes towards the nutritional aspect of the family towards the prevention of dental caries among the school going children would reduce the prevalence at this tender age of life.

\section{Acknowledgements}

Authors are grateful to the students and authority of Tarasundari Balika Vidyabhaban, Howrah, West Bengal, India for their cooperation in the study. Partial financial supports were provided from Departmental Grant [B.I. 65 (8 \& 9)], Department of Anthropology, UCSTA, University of Calcutta and SAP program [ASIHSS Program] (UGC), Department of Anthropology, UCSTA, University of Calcutta.

\section{REFERENCES}

Alvarez, J. O. (1995). Nutrition, tooth development, and dental caries. American Journal of Clinical Nutrition, 61, 410S-416S.

Alvarez, J. O., Eguren, J. C., Caceda, J., \& Navia, J. M. (1990). The effect of nutritional status on the age distribution of dental caries in the primary teeth. Journal of Dental Research, 69, 1564-1566. doi:10.1177/00220345900690090501

Banerjee, P., \& Banerjee, A. R. (1992). Eruption of permanent teeth in Bengalee school children. In J. R. Lucaks (Ed.), Culture ecology and dental anthropology. Journal of Human Ecology (pp. 31-33). Delhi: Kamla Raj Enterprises.

Barrett, M. J., \& Brown, T. (1966). Eruption of deciduous teeth in Australian Aborigines. Australian Dental Journal, 11, 43-50. doi:10.1111/j.1834-7819.1966.tb02150.x

Bergandi, L., Defabianis, P. Re. F., Preti, G., Aldieri, E., Garetto, S., Bosia, A., \& Ghigo, D. (2007). Absence of soluble CD14 in saliva of young patients with dental caries. European Journal of Oral Science, 115, 93-96. doi:10.1111/j.1600-0722.2007.00437.x

Bjarnason, S., Care, R., Berzina, S., Brinkmane, A., Rence, I., Mackevica, I., Paeglite, I., \& Senakola, E. (1995). Caries experience in Latvian nursery school children. Community Dentistry and Oral Epidemiology, 23, 138-141. doi:10.1111/j.1600-0528.1995.tb00217.x

Chiu, S. H., Dimarco, M. A., \& Prokop, J. L. (2012). Childhood obesity and dental caries in homeless children. Journal of Pediatric Health Care, Epub ahead of print.

Cleaton-Jones, P., Fatti, P., \& Bönecker, M. (2006). Dental caries trends in 5- to 6-year-old and 11- to 13-year-old children in three UNICEF designated regions - Sub Saharan Africa, Middle East and North Africa, Latin America and Caribbean. International Dental Journal, 56, 294-300.

David, J., Wang, N. J., Astrøm, A. N., \& Kuriakose, S. (2005). Dental caries and associated factors in 12-year-old schoolchildren in Thiruvananthapuram, Kerala, India. International Journal of Paediatric Dentistry, 15, 420-428. doi:10.1111/j.1365-263X.2005.00665.X

Demirjian, A., Buschang, P. H., Tanguay, R., \& Patterson, D. K. (1985). Interrelationships among measures of somatic, skeletal, dental, and sexual maturity. American Journal of Orthodontics and Dentofacial Orthopedics, 88, 433-438.

Delgado-Angulo, E. K., \& Bernabé, E. (2006). Influence of host-related risk indicators on dental caries in permanent dentition. Acta Odontol Latinoam, 19, 85-92.

Garn, S. M., Lewis, A. B., \& Polacheck, D. L. (1960). Interrelations in Dental Development. I. Interrelationships within the Dentition.
Journal of Dental Research, 39, 1049-1055.

doi:10.1177/00220345600390050901

Granath, L., Cleaton-Jones, P., Fatti, P., \& Grossman, E. (1991). Correlations between caries prevalence and potential etiologic factors in large samples of 4-5-year-old children. Community Dentistry and Oral Epidemiology, 19, 257-260.

doi:10.1111/j.1600-0528.1991.tb00162.x

Ghosh, J. R., \& Bandyopadhyay, A. R. (2006). Income, birth order, siblings and anthropometry. Human Biology, 78, 733-741. doi:10.1353/hub.2007.0012

Ghosh, J. R., \& Bandyopadhyay, A. R. (2009). Prevalence of thinness and overweight among urban adolescents of West Bengal, India. Journal of Tropical Pediatrics, 55, 340-341. doi:10.1093/tropej/fmp002

Holm, A. K. (1990). Caries in the preschool child-International trends. Journal of Dentistry, 18, 291-295. doi:10.1016/0300-5712(90)90125-X

Jalili, V. P., Sidhu, S. S., \& Kharbanda, O. P. (1993). Status of dental caries and treatment needs in tribal children of Mandu (Central India). Journal of Pierre Fauchard Academy, 7, 7-15.

Johansson, I., Saellström, A. K., Rajan, B. P. \& Parameswaran, A. (1992). Salivary flow and dental caries in Indian children suffering from chronic malnutrition. Caries Research, 26, 38-43. doi:10.1159/000261425

Honne, T., Pentapati, K., Kumar, N., \& Acharya, S. (2011). Relationship between obesity/overweight status, sugar consumption and dental caries among adolescents in South India. International Journal of Dental Hygiene. doi:10.1111/j.1601-5037.2011.00534.x

Kaul, S., Saini, S., \& Saxena, B. (1975). Emergence of permanent teeth in school children in Chandigarh, India. Archives of Oral Biology, 20, 587-593. doi:10.1016/0003-9969(75)90079-5

Kaul, S. S., \& Pathak, R. K. (1983). Estimation of calendar age from the emergence times of permanent teeth in Punjabi children in Chandigarh, India. Annals of Human Biology, 15, 307-309.

Kerosuo, H., \& Honkala, E. (1991). Caries experience in the primary dentition among groups of Tanzanian and Finnish $3-7$ years old children. Community Dentistry and Oral Epidemiology, 19, 272-276. doi:10.1111/j.1600-0528.1991.tb00166.x

Klingberg, G., Lingström, P., Oskarsdóttir, S., Friman, V., Bohman, E., \& Carlén, A. (2007). Caries-related saliva properties in individuals with 22q11 deletion syndrome. Oral Surgery, Oral Medicine, Oral Pathology, Oral Radiology and Endodontology, 103, 497-504. doi:10.1016/j.tripleo.2006.09.018

Kuczmarski, R. J., Ogden C. L., Grummer-Strawn, L. M., Flegal, K. M., Guo, S. S., Wei, R., Mei, Z., Curtin, L. R., Roche, A. F., \& Johnson, C. L. (2000). CDC growth charts: United States. Advanced Data, 8, $1-27$.

Kuczmarski, R. J., Ogden, C. L., Guo, S. S., Grummer-Strawn, L. M., Flegal, K. M., Mei, Z., Wei, R., Curtin, L. R., Roche, A. F., \& Johnson, C. L. (2002). CDC Growth Charts for the United States: Methods and development. Vital and Health Statistics, 11, 1-190.

Lenander-Lumikari, M., \& Loimaranta, V. (2000). Saliva and dental caries. Advances in Dental Research, 14, 40-47. doi:10.1177/08959374000140010601

Leroy, R., Bogaerts, K., Lesaffre, E., \& Declerck, D. (2005). Multivariate survival analysis for the identification of factors associated with cavity formation in permanent first molars. European Journal of Oral Sciences, 113, 145-152. doi:10.1111/j.1600-0722.2005.00199.X

Li, Y., \& Wang, W. (2002). Predicting caries in permanent teeth from caries in primary teeth: An eight-year cohort study. Journal of Dental Research, 81, 561-566. doi:10.1177/154405910208100812

Lohman, T. G., Roche, A. F., \& Martorel, R. (1988). Anthropometric standardization reference manual. Chicago: Human Kinetics Books.

Ludwig, T. G., Kean, M. R., \& Pearce, E. I. F. (1964). The dental condition of a rural Maori population. New Zealand Dental Journal, 60, 106-114.

Mahejabeen, R., Sudha, P., Kulkarni, S. S., \& Anegundi, R. (2006). Dental caries prevalence among preschool children of Hubli: Dharwad City. Journal of Indian Society of Pedodontics and Preventive Dentistry, 24, 19-22. doi:10.4103/0970-4388.22829

Malina, R. M., Bouchard, C., \& Bar-Or, O. (2004). Growth, maturation, 
and physical activity (2nd ed.). Chicago: Human Kinetic Books.

Mandal, K. P., Tewari, A. B., Chawla, H. S., \& Gauba, K. D. (2001). Prevalence and severity of dental caries and treatment needs among population in the Eastern states of India. Journal of Indian Society of Pedodontics and Preventive Dentistry, 19, 85-91.

Mascarenhas, A. K. (1999). Determinants of caries prevalence and severity in higher SES Indian children. Community Dental Health, 16, 107-113.

Mukherjee, D. K. (1973). Deciduous dental eruption in low income group Bengali hindu children. Journal of Tropical Pediatrics \& Environmental Child Health, 19, 207-210.

Narksawat, K., Tonmukayakul, U., \& Boonthum, A. (2009). Association between nutritional status and dental caries in permanent dentition among primary schoolchildren aged 12 - 14 years, Thailand. Southeast Asian Journal of Tropical Medicine and Public Health, 40, 338-344.

O’Sullivan, D. \& Tinanoff, N. (1996). The association of early dental caries patterns with caries incidence in preschool children. Journal of Public Health Dentistry, 56, 81-83. doi:10.1111/j.1752-7325.1996.tb02401.x

Prendergast, M. J., Williams, S. A., \& Curzon, M. E. (1989). An assessment of dental caries prevalence among Gujurati, Pakistani and white Caucasian five-year-old children resident in Dewsbury, West Yorkshire. Community Dent Health, 6, 223-232.

Psoter, W. J., Reid, B. C., \& Katz, R. V. (2005). Malnutrition and dental caries: A review of the literature. Caries Research, 39, 441-447. doi:10.1159/000088178

Raadal, M., Elhasan, F. E., \& Ramusson, P. (1993). Prevalence of caries in groups of children aged 4 - 5 and 7 - 8 years in Kartoum, Sudan. International Journal of Paediatric Dentistry, 3, 9-15. doi:10.1111/j.1365-263X.1993.tb00041.X

Rahmatulla, M., \& Wyne, A. H. (1993). Relationship between caries, water fluoride level and socioeconomic class in 15-year-old Indian school children. Indian Journal of Dental Research, 4, 17-20.

Rami-Reddy, V. Vijayalakshmi, P. B., \& Chandrasekhar-Reddy, B. K. (1986). Deciduous Tooth emergence and physique of Velama children of Southeastern Andhra Radesh, India. Acta Odontol Pediatr, 7, 1-5.

Rao, S. P., \& Bharambe, M. S. (1993). Dental caries and periodontal diseases among urban, rural and tribal school children. Indian Pediatrics, 30, 759-764.
Reid, D. J., \& Dean, M. C. (2005). Variation in modern human enamel formation times. Journal of Human Evolution, 50, 329-346. doi:10.1016/j.jhevol.2005.09.003

Robinow, M. (1973). The eruption of the deciduous teeth (factors involved in timing). Journal of Tropical Pediatrics \& Environmental Child Health, 19, 200-205.

Russell, A. L., Leatherwood, E. C., Van Hien, L., \& Van Reen, R. (1965). Dental caries and nutrition in South Vietnam. Journal of Dental Research, 44, 102-111. doi:10.1177/00220345650440010301

Shah, N. (2003). Gender issues and oral health in elderly Indians. International Dental Journal, 6, 475-484. doi:10.1002/j.1875-595X.2003.tb00890.X

Shah, N., \& Sundaram, K. R. (2004). Impact of socio-demographic variables, oral hygiene practices, oral habits and diet on dental caries experience of Indian elderly: A community-based study. Gerodontology, 2, 143-150.

Touger-Decker, R., \& Mobley, C. C. J. (2007). Position of the American dietetic association: Oral health and nutrition. Journal of the American Dietetic Association, 81, 418-428.

Uehara, A., Sugawara, S., Watanabe, K., Echigo, S., Sato, M., Yamaguchi, T., \& Takada, H. (2003). Constitutive expression of a bacterial pattern recognition receptor, CD14, in human salivary glands and secretion as a soluble form in saliva. Clinical and Diagnostic Laboratory Immunology, 10, 286-292.

Ulijaszek, S. A., \& Lourie, J. A. (1994). Intra- and inter-observer error in anthropometric measurement. Anthropometry: The individual and the population. Cambridge: Cambridge University Press.

Venkaiah, K., Damayanti, K., Nayak, M. U., \& Vijayaraghavan, K. (2002). Diet and nutritional status of rural adolescents in India. European Journal of Clinical Nutrition, 56, 1119-1125. doi:10.1038/sj.ejcn.1601457

World Health Organization (1985). Measuring nutritional status. Geneva: World Health Organization.

World Health Organization (1995). Physical status: The use and interpretation of anthropometry. Report of a WHO expert committee. Geneva: WHO.

World Health Organization (1997). Oral health survey basic methods (4th ed.). Geneva: WHO.

Yassin, I., \& Low, T. (1975). Caries prevalence in different racial groups of schoolchildren in West Malaysia. Community Dentistry and Oral Epidemiology, 3, 179-183. 